\title{
A New Method for Measuring Organizational Authority and Accountability: Quantitative Approach
}

Article history:

Received: 25 June 2018

Sent for revision: 26 June 2018

Received in revised form: 16 August 2018

Accepted: 16 August 2018

Available online: 2 October 2018

\begin{abstract}
This paper suggests a new approach to measuring the alignment of authority and accountability of different positions within an organization. According to the controllability principle, accountability and authority should be aligned for achieving better organizational results. Nevertheless, there is still a research gap in the quantification of this alignment. Thus, this paper aims to improve the method of measuring authority and accountability. It proposes a new approach to measuring authority and accountability, as well as the rules for defining their alignment. The suggested model is tested through the research conducted in 241 organizations. Top managers from the organizations answered the structured questionnaire. The results show statistically significant dependence between the alignment of authority and accountability and organizational performance. In order to overcome the identified limitations of the conducted research, it is necessary to do some additional research to verify general applicability of the proposed approach.
\end{abstract}

Keywords: organizational alignment, controllability principle, authority, accountability, organizational performance, span of authority, span of accountability

\footnotetext{
1 University of Belgrade, Faculty of Organizational Sciences, jevtic.milos@fon.bg.ac.rs

2 University of Belgrade, Faculty of Organizational Sciences

3 University of Belgrade, Faculty of Organizational Sciences
} 
Jevtić M., et al: A New Method for Measuring Organizational Authority and...

\title{
Novi metod merenja autoriteta i odgovornosti u organizacijama: kvantitativni pristup
}

\begin{abstract}
Apstrakt: $U$ ovom radu se predlaže novi način merenja usklađenosti autoriteta $i$ odgovornosti različitih pozicija u organizaciji. Prema principu kontrolabilnosti, odgovornost $i$ autoritet treba da budu usklađeni kako bi organizacija ostvarila bolje rezultate. Uprkos tome, još uvek nedostaju metode kojim se ova usklađenost kvantifikuje. Zbog toga, cilj ovog rada je da unapredi način merenja autoriteta $i$ odgovornosti. $U$ radu se predlaže novi način merenja autoriteta $i$ odgovornosti, kao i pravila za definisanje njihove usklađenosti. Predloženi metod je primenjen u istraživanju koje je sprovedeno u 241 organizaciji. Top menadžeri iz izabranih organizacija su odgovarali na pitanja iz strukturiranog upitnika. Rezultati su pokazali da postoji statistički značajna zavisnost između usklađenosti autoriteta $i$ odgovornosti $i$ organizacionih učinaka. Kako bi se prevazišla ograničenja sprovedenog istraživanja navedena u radu, u budućim istraživanjima bi trebalo da se potvrdi i verifikuje univerzalna primenljivost predstavljenog pristupa.
\end{abstract}

Ključne reči: organizaciona usklađenost, princip kontrolabilnosti, autoritet, odgovornost, organizacioni učinci, raspon autoriteta, raspon odgovornosti

\section{Introduction}

Alignment of authority and accountability, also known as the controllability principle is an emerging research topic in recent years. Different authors suggest that, in accordance with the controllability principle (Antle \& Demski, 1988), authority and accountability should be mutually aligned (Merchant \& Otley, 2006; Arya, Glover, \& Radhakrishnan, 2007; Giraud, Langevin, \& Mendoza, 2008; Bedford, Teemu, \& Mikko, 2016). The second group of authors, who examined this problem through the alignment of organizational elements, also emphasize the need for aligning authority and accountability for achieving better organizational effects (Khandwalla, 1973; Mintzberg, 1979; Simons, 2005; Daft, Jonathan, \& Willmott, 2010; Simons, 2013).

Although literature highlights the importance of authority and accountability alignment, practice has shown that the amount of authority is not always followed by the appropriate amount of accountability (Lunenburg, 2012). These deviations are going in both directions. There are examples when accountability is lower than the authority, when management control system is not adequately developed (Merchant \& Van der Stede, 2007). Also, there are some different examples when managers are accountable for things that are not entirely under their influence (Merchant \& Otley, 2006; Simons, 2010; Fischer, 2010). 
Jevtić M., et al: A New Method for Measuring Organizational Authority and...

The authors who wrote on this topic have different ways of defining the alignment of the variables (Arya et al., 2007; Fischer, 2010). In order to align authority and accountability, some authors developed different ways of their categorization, which enables a better comparison of the elements (Otley, 2016). Robert Simons (1994) has an interesting approach and uses two analytic concepts in his research: the span of authority and the span of accountability. This concept is a step towards the quantification of the observed elements. However, up to now, the analysis of these alignments is at the low level of quantification, which reduces its objectivity.

Although organizations deal with this issue, science is behind the practice, and there is still no established methodology for measuring this alignment. Management of the possible discrepancies is mainly based on some empirical knowledge and experience. Thus, this paper aims to improve the method of measuring authority and accountability. Besides, it analyses the impact of authority and accountability alignment based on a new method of quantifying these elements. For measuring authority and accountability, the paper defines a 7-level Likert-type scale (Jevtić, Jovanović, \& Krivokapić, 2018). In this way, the research provides greater objectivity when determining the values of these variables. Quantification of authority and accountability also leads to a more straightforward and objective definition of their alignment. The conducted survey tested the model proposed in this research by comparing the alignment of authority and accountability with the organizational performance.

The paper is organized as follows: Section 2 presents the literature review and proposes a new way of measuring the alignment of authority and accountability. Section 3 introduces the model and explains how the variables in the model will be measured. Section 4 illustrates the results obtained by statistical analysis of data. Discussion and conclusions are offered in Section 5 .

\section{Literature review on controllability principle}

Controllability principle, or alignment of authority and accountability, is considered as one of the essential principles in management (Ocansey \& Enahoro, 2012; Meier \& Bohte, 2000). In the performance management literature, the controllability principle assumes the assertion that managers should be accountable for the results that are exclusively under their influence (or under their jurisdiction) and which they may affect (Burkert, Fischer, \& Schäffer, 2011). In other words, managers should not be accountable for underperformance or be associated with good results they cannot affect (Bouwens \& Van Lent, 2007; Giraud et al., 2008).

The authority, as a possibility of influence, can be defined in different ways. Authority is the right to perform or command (Mintzberg, 1989). It allows 
Jevtić M., et al: A New Method for Measuring Organizational Authority and...

managers to select actions that affect a part or the whole organization (Aghion \& Jean, 1997). A broader definition includes all management activities, as well as resource management, which are necessary for achieving the defined goals (Merchant \& Otley, 2006). According to this broader viewpoint, authority includes strategy implementation, but also the modes of learning, innovation, and adaptation (Simons, 1994). The complement to the authority is accountability. To be accountable means that individuals are rewarded when good results are achieved and punished when bad things happen (Merchant \& Otley, 2006).

Management undertakes various activities to align authority and accountability, and apply the controllability principle (Merchant, 1989). They seek to eliminate differences between authority and accountability, as well as to exclude uncontrollable managerial performance measures (Merchant \& Van der Stede, 2007).

When the delegated authority is not equal to the assigned accountability, there is often a dissatisfaction among the employees, and valuable energy and resources are lost (Montana \& Charnov, 2000). In addition to the possible frustrations among employees due to excessive superiors' expectations (Merchant, 1989), there is a possibility of "entrepreneurial behaviour" among the employees. In situations where accountability is higher than the authority, it may occur that solution are sought out of the established rules and beyond the available resources (Simons, 2010). This "entrepreneurial gap" arises as an aspiration of management to develop innovations and exploration for employees at lower levels (Frow, Marginson, \& Ogden, 2005; Simons, 2010).

One of the reasons for a discrepancy between authority and accountability are possible difficulties to distinguish uncontrollable and controllable factors on performance measures (Goold, 1993; Merchant \& Otley, 2006). Is the production line failure the result of a manager's negligence or is it an unforeseen event? Another group of reasons arises from the manager's desire to affect factors that are not controllable. This means that managers must find a way to influence performance measures, even if they are induced by factors that cannot be controlled. For example, an increase in energy products price, which cannot be affected, can stimulate managers to find some ways to reduce the need for energy products in production. If managers can influence effects that a specific factor has on the results, they can be accountable for it, even if they cannot affect that factor itself. If they are entirely separated from the influence of this factor, such as the price of energy products, they will not make appropriate improvements (Antle \& Demski, 1988). Encouraging initiatives at lower levels in the hierarchy is a good way to relieve top management of additional pressure and make a company more responsive to changes in the market. 
Jevtić M., et al: A New Method for Measuring Organizational Authority and...

Most of the research from this discipline was field research, which assumed employees interview, or evaluation of the current state of the organization. Alignment of organizational elements was usually compared with qualitative outcomes within an organization (Simons, 2013; Giraud, Langevin, \& Mendoza, 2008). For example, Simons classifies organizations according to the dominant strategy of the organization at the moment of the observation (Simons, 2013). Also, organizational alignment was compared with the data on managerial efficiency collected by the interviewers (Merchant, 1989; Burkert, Fischer, \& Schäffer, 2011). Burket et al. (2011) compare alignment with the 9-level scale to determine the managerial performance. Respondents evaluated themselves to "indicate the extent to which their performance was below or above average". Besides, there were some attempts to compare the organizational characteristics with the quantitative performance measures. Bouwens \& Van Lent (2007) determined how is the authority of managers associated with expenses and revenues, as well as the non-financial measures such as market share and customer satisfaction. Nevertheless, the paper does not determine the relationship with the controllability principle.

Since the literature review identified the research gap in the quantitative measuring of the organizational alignment and performance, this paper aims to improve the method of measuring authority and accountability. The paper will examine whether the new measurement method gives similar results to some previous research. The influence of authority and accountability will be discussed based on the quantified measures of these elements. In contrast to the categorical methods, which prevailed in the previous works, this paper aims to propose a new approach to measuring authority and accountability. The assumption proposed in the paper is that companies with aligned elements achieve better organizational results than companies with the mismatch of the observed elements. Therefore, the paper proposes the following hypothesis:

H1: Alignment of authority and accountability has a positive correlation with organizational performance.

The hypothesis will be tested by the proposed measuring scale, and the results will be presented in the following sections.

\section{Methodology}

\subsection{Data collection and sample size}

In order to verify the hypothesis, a survey was conducted to measure the authority and accountability and compare the appropriate performance indicators. The research was implemented on a sample of 241 companies in 
Jevtić M., et al: A New Method for Measuring Organizational Authority and...

Serbia. All examined companies have achieved revenue of more than 22 million euros, have more than 250 employees, and are in business for more than five years. Data were collected by a group of final-year students of a business school. From the list of top 300 companies with the highest revenue, they contacted a person from the senior management that could provide the requested data. To each respondent, they explained the purpose of the research, procedure of the survey, and the structure of the questionnaire. Each interviewer was responsible for conducting the poll in only one company. From the list of 300 , they collected the responses from 241 companies.

The data related to the performance of the examined companies were collected from the publicly available data for the calendar year of the survey. The researchers collected the data on the business revenue, size of the company (number of employees, value of assets), data on the achieved financial results, as well as data on the economic sector. All companies from the sample are categorized into five sectors: heavy industry, light industry, construction, tertiary industry, quaternary industry.

Questionnaires with closed and open questions were used to collect the data on organizational elements. Respondents in the research were managers at senior positions, so the collected data was related to the authority and accountability of the highest hierarchy level. The total number of organizations that participated in the survey was 241.

\subsection{Research model}

The model of interdependence of variables in the research is in Figure 1.

Figure 1. The model of interdependence of variables in the research

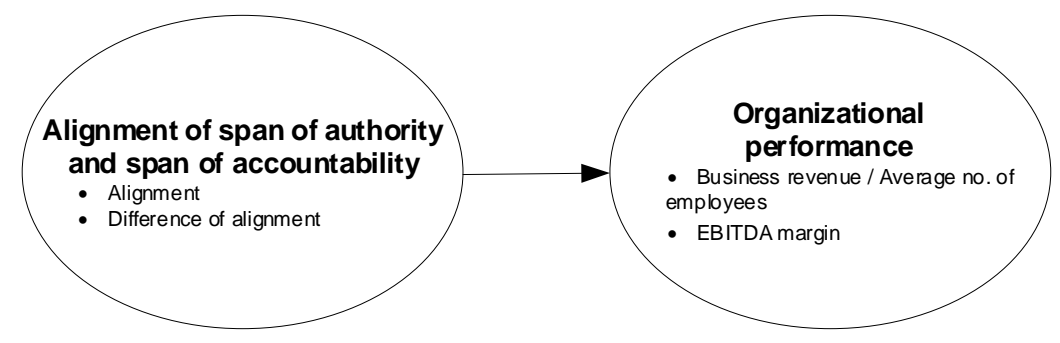

Source: Authors

The independent variable in the research is the Alignment of authority and accountability. The value of this variable is obtained based on the measured values of the span of authority and the span of accountability (as explained in 
Jevtić M., et al: A New Method for Measuring Organizational Authority and...

the following subsection). The research defines two derived variables of the Alignment of organizational elements (Alignment and Difference of alignment) and examines the influence on the dependent variable(s) (Business revenue/Average number of employee and EBITDA margin). Dependent variables in the model are indicators of the organizational performance. The study examines the correlation between the two performance indicators and two variables related to the alignment of authority and accountability.

\subsection{Measuring span of authority and span of accountability}

Authority of some positions in the organization is measured through a variable defined as the span of authority (Simons, 1994). Authority refers to the influence, permissions, and resources of an organization that are assigned to one position, in order to achieve the goals for which a position is defined (Jevtić, 2013). Thus, the span of authority assumes the size of the influence, permissions, and resources assigned to a particular position.

The managerial positions will have a span of authority that represents the sum of the authority of all positions that are below the observed position in the hierarchical chain, including the resources, influence and permissions assigned directly to that position.

To determine the value of the span of authority, this research defines a 7-level Likert-type scale. The scale has 7 numerals (numbers in this case) and rules for assigning a numeral to a defined variable. The defined scale represents a discrete scale with discrete measures that can take only specific values (integers in this case) and cannot have values between integers (Stevens, 1946). It is an ordinary scale since each subsequent number in a row represents a higher value than the previous one.

The values of a span of authority were determined based on the defined ordinal scale (Appendix 1, Table 11), and on the corresponding questions from the questionnaires used in the survey. The span of authority is estimated based on the assigned authority, activities, and resources to the observed position.

The first part of the survey contained the data on the respondent's position, the name of the organization and number of full- and part-time employees. The second part of the questionnaire had the graphical model of Porter's value chain, with labelled activities (i.e. company's infrastructure - legal, accounting, financial management, security etc.) and description of each activity category (Porter, 1985). The respondent could choose one or more activities for which he is in charge.

The span of authority measurement was performed in several iterations. In the first phase, three qualified researchers (the authors of this paper) 
Jevtić M., et al: A New Method for Measuring Organizational Authority and...

estimated the span of authority for each respondent, independently of each other. The Cronbach alpha coefficient was calculated to determine the internal consistency of the researchers' estimation of the span of authority values, and thus the reliability of proposed scale. The result for the alpha coefficient suggests that the reliability of scale is good (>0.80) (George \& Mallery, 2003). In the second round, the values that differed between the researchers for the same questionnaire were harmonized, after which a final decision was made for the span of authority value. In a case of different estimations, the researches followed the principles of Delphi method until the consensus was achieved (Okoli \& Pawlowski, 2004).

The variable of accountability is measured by the span of accountability (Simons, 1994). The span of accountability is defined as the scope of the capabilities (availability of resources, influence, and authority) available for achieving the measurable effects assigned to a particular position. In other words, how many different ways managers and employees have at their disposal that might influence the achievement of the assigned accountabilities, i.e. achieving the defined effects (Simons, 1994). The span of accountability will depend on the characteristics of the assigned goals that employees in those positions have to achieve. Besides, not only the number and type of measurable dimensions matter, but also the way in which goals can be achieved.

The principle that applies in defining the span of accountability for a position is similar to the principle that was relevant for defining the span of authority. A position has a span of accountability that depends on the performance measures assigned to that particular position, but also the performance measurements that are below in the hierarchy.

The span of accountability is determined based on the answers to the third part of the survey. The questions that were related to the span of accountability of the respondents were divided into four groups:

1. Accountability for efficiency and effectiveness of the operations

2. Accountability for financial results

3. Accountability for the clients of the organization

4. Accountability for learning and development of the employees.

The claims listed in the questionnaire were based on the similar academic research conducted in Finland (Jänkälä, 2007). The study was related to analyse of the use of management control systems in small and medium enterprises. Measurement of the span of accountability was performed by the authors in several iterations, by following the same process as for span of authority (Appendix 1, Table 12). After the first phase the authors determined the reliability of the proposed scale for the span of accountability values, by calculating the Cronbach alpha coefficient. The result suggests that the 
Jevtić M., et al: A New Method for Measuring Organizational Authority and...

reliability of scale is acceptable (>0.70) (George \& Mallery, 2003). To determine the value of the span of accountability, the paper defines a 7-level Likert-type scale and rules to assign a numeral to a defined variable. The defined scale is also a discrete ordinal scale with discrete measures that can take only integer values.

\subsection{Measurement of alignment of authority and accountability}

The alignment of authority and accountability is determined by the values of the measured span of authority and span of accountability. All cases with the same values of the variables represent the cases with the alignment. In the opposite situations, when the measured values are different, it is considered that there is a certain mismatch between the elements.

Figure 2 represents one a case of the mismatch between the elements (when the span of authority is higher than the span of accountability).

Figure 2. Example of authority and accountability alignment

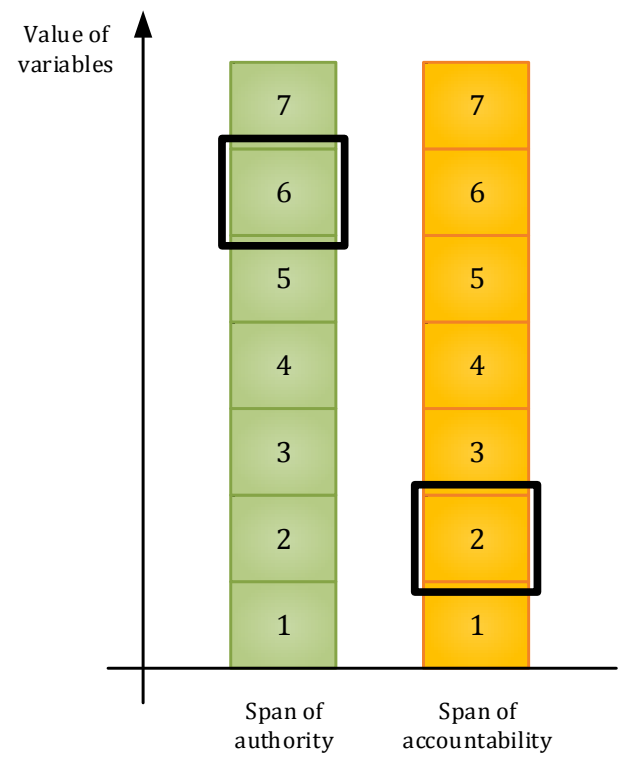

Source: Authors

Figure 2 illustrates the amount of the assigned resources and accountabilities shown on the sliders, which takes values from narrow to a wide span of authority and from narrow to a wide span of accountability. Scales of 
Jevtić M., et al: A New Method for Measuring Organizational Authority and...

measurement are defined so that two elements are aligned when the sliders have the same values, that is, when they are located next to each other.

In the research, the authors defined two variables that represent the measure of the alignment of organizational elements:

- The first variable is defined as Alignment

- The second variable is defined as Difference of Alignment.

The values of the alignment variable are defined in the following table:

Table 1. The values of the alignment variable

\begin{tabular}{ll}
\hline Variable values & In cases... \\
\hline Aligned accountability & $\begin{array}{l}\text { When both variables have the same values (i.e. span of } \\
\text { authority is } 4 \text { and span of accountability is 4) }\end{array}$ \\
& $\begin{array}{l}\text { When the span of authority is higher than the span of } \\
\text { accountability (i.e. span of authority is } 5 \text {, and span of } \\
\text { Lower accountability } \\
\text { accountability is 3) }\end{array}$ \\
When the span of authority is lower than the span of \\
Higher accountability & $\begin{array}{l}\text { accountability (i.e. span of authority is } 4 \text {, and span of } \\
\text { accountability is 5) }\end{array}$ \\
\hline
\end{tabular}

Source: Authors

The variable is marked as "aligned accountability" when the span of authority and the span of accountability have the same values. When these two values differ, there is a mismatch between the elements. In the case of elements mismatch, there are two possible situations: when the span of accountability is lower, or when it is higher than the span of authority.

In addition to the variable Alignment, research defined Difference of Alignment, which is calculated as the difference between the values of the span of authority and span of accountability:

Difference of Alignment $=$ Span of Accountability - Span of Control (1)

This variable will have positive values when the span of accountability is higher than the span of authority, and vice versa, it will have negative values when the span of accountability is lower than the span of authority. When the spans are aligned, the value will have zero value.

Unlike Alignment variable, Difference of Alignment shows not only which of the two spans has higher value, but the size of the mismatch. The difference of alignment can take values from -6 to +6 , but this is a theoretical possibility. In the conducted research the values of this variable take values from -3 to +3 . 
Jevtić M., et al: A New Method for Measuring Organizational Authority and...

\subsection{Measuring the organizational performance}

Productivity and economy were used as the criteria of organizational performance (Perrow, 1986). These indicators are often used in the research for measuring the organizational performance of higher managerial positions (Bouwens \& Van Lent, 2007).

Business Revenue per employee is used as a productivity criterion:

$$
\frac{\text { Business Revenue }}{\text { Average number of employees }}
$$

This productivity indicator compares business operating revenue in one year and the average number of employees in the same year.

EBITDA margin is used as an economy criterion:

$$
\frac{\text { EBITDA }}{\text { Business Revenue }}
$$

EBITDA margin shows the amount of money remained for covering the costs of depreciation, financing, and taxes, after settling expenses. This indicator does not include the effects of fixed assets (depreciation costs), taxes and sources of funds (interest costs) (Kaplan \& Ruback, 1995; Zhang, Zhou, \& Zhou, 2007). It also excludes sources of funds as one of the factors that affect organizational performance.

Prior to the analysis of the organizational elements alignment, it was examined whether there is the influence of the sectorial affiliation of the company. To exclude this influence, the authors performed ANOVA variance analysis. In this concrete case, the importance of sectorial affiliation (total of 5 sectors) is examined on the selected performance criteria. The analysis shows that the sector affiliation does not influence the organizational effects used in this study (tables 2 and 3 , values $p>0.05$ for both criteria).

Table 2. Variation analysis by sector for variable Business Revenue/Average number of employees

\begin{tabular}{|l|c|r|r|r|r|}
\hline & \multicolumn{1}{|c|}{$\begin{array}{c}\text { Sum of } \\
\text { squares }\end{array}$} & $\begin{array}{c}\text { Degree } \\
\text { of } \\
\text { freedom }\end{array}$ & $\begin{array}{c}\text { Mean } \\
\text { square } \\
\text { value }\end{array}$ & $\mathbf{F}^{*}$ & Significance \\
\hline Between groups & \multicolumn{1}{|c|}{$68,516.444$} & 4 & $17,129.111$ & 1.125 & .345 \\
\hline Within groups & $3,593,043.224$ & 236 & $15,224.759$ & & \\
\hline Total & $3,661,559.668$ & 240 & & & \\
\hline
\end{tabular}

Source: Authors 
Jevtić M., et al: A New Method for Measuring Organizational Authority and...

Table 3. Variation analysis by sector for variable EBITDA margin

\begin{tabular}{|l|r|r|r|r|r|}
\hline & \multicolumn{1}{|c|}{$\begin{array}{c}\text { Sum of } \\
\text { squares }\end{array}$} & $\begin{array}{c}\text { Degree } \\
\text { of } \\
\text { freedom }\end{array}$ & $\begin{array}{c}\text { Mean } \\
\text { square } \\
\text { value }\end{array}$ & $\mathbf{F}^{*}$ & Significance \\
\hline Between groups & .003 & 4 & .001 & .069 & .991 \\
\hline Within groups & 2.557 & 236 & .011 & & \\
\hline Total & 2.560 & 240 & & & \\
\hline
\end{tabular}

Source: Authors

Based on the results of the analysis (Sig. $=0.345$ and Sig. $=0.991$ ) one can conclude that for indicators Business Revenue per employee and EBITDA margin the hypothesis can be accepted that there is no effect of sectorial affiliation on the mean values of these indicators (Pallant, 2011).

\section{Results}

The first analysis refers to the examination of the difference in performance between three groups of companies. The organizations are divided according to the achieved alignment: aligned accountability, higher accountability, and lower accountability. For this purpose, the variance analysis (ANOVA) is used, and it was a single-factor analysis because there is only one observed factor, the Alignment of authority and accountability (Pallant, 2011).

Table 4. Descriptive statistics for variable alignment of organizational structure and performance measurement system

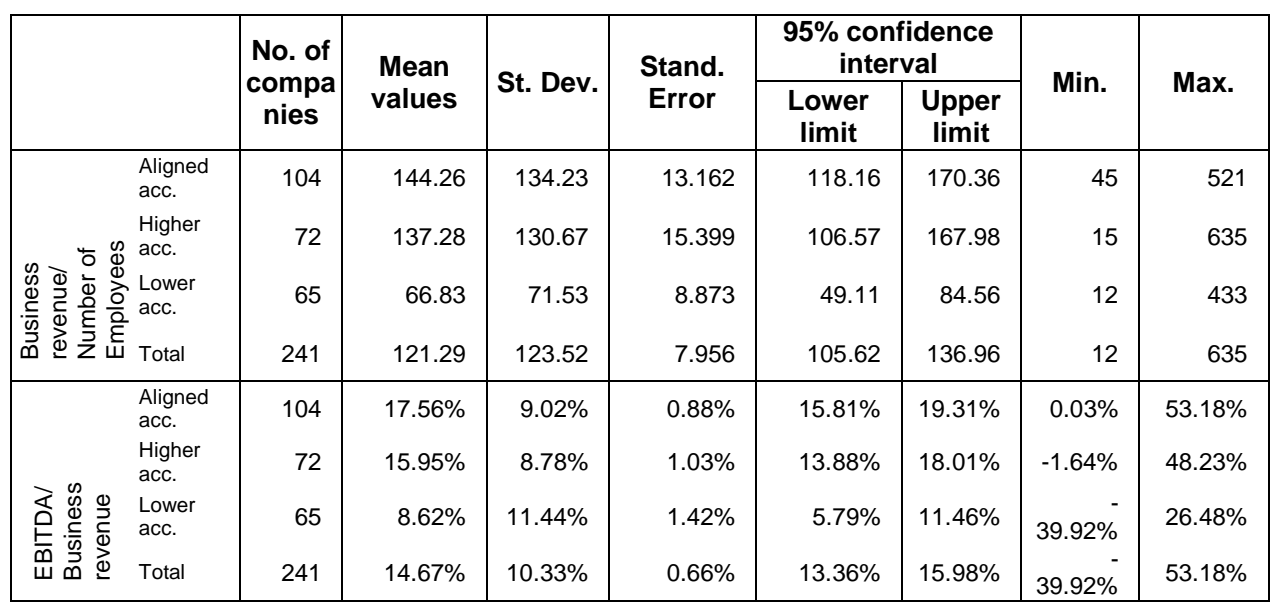

Source: Authors 
Jevtić M., et al: A New Method for Measuring Organizational Authority and...

Table 4 shows the descriptive statistics for the performance indicators. The results show that the highest mean values of the selected indicators (Business Revenue/Number of Employees and EBITDA margin) are achieved in organizations that have aligned elements of organizational structure and accountability.

Table 5 shows the results of Leven's test of homogeneity of variance, which examines the equality of variation for performance indicators in each of the three examined groups of companies. The value of significance is lower than 0.05 for indicator Business revenue/Number of Employees, which implies that variances among groups are different, while the significance value is higher than 0.05 for indicator EBITDA margin, so that the assumption about the homogeneity of the variance is valid.

Table 5. Leven's test of homogeneity of variance and alignment variable

\begin{tabular}{|l|c|c|c|c|}
\hline & $\begin{array}{c}\text { Leven's } \\
\text { statistics }\end{array}$ & df1 & df2 & Sig. \\
\hline Business revenue/Number of Employees & 10.124 & 2 & 238 & .000 \\
\hline EBITDA margin & .891 & 2 & 238 & .412 \\
\hline
\end{tabular}

Source: Authors

Table 6 shows the significance value lower than 0.05 for both performance indicators, so it can be concluded that there is a statistically significant difference between the mean values of the performance indicators of the observed groups.

Table 6. Variation analysis for variable alignment

\begin{tabular}{|l|l|r|r|r|r|r|}
\hline \multicolumn{2}{|c|}{} & \multicolumn{1}{c|}{$\begin{array}{c}\text { Sum of } \\
\text { squares }\end{array}$} & $\begin{array}{c}\text { Degree } \\
\text { of } \\
\text { freedom }\end{array}$ & $\begin{array}{c}\text { Mean } \\
\text { square } \\
\text { value }\end{array}$ & $\mathbf{F}^{*}$ & Sig. \\
\hline $\begin{array}{l}\text { Business } \\
\text { revenue/ } \\
\begin{array}{l}\text { Number of } \\
\text { Employees }\end{array}\end{array}$ & $\begin{array}{l}\text { Between } \\
\text { groups }\end{array}$ & 266052.095 & 2 & 133026.047 & 9.324 & .000 \\
\cline { 2 - 8 } & Within groups & 3395507.573 & 238 & 14266.839 & & \\
\cline { 2 - 8 } & Total & 3661559.668 & 240 & & & \\
\hline $\begin{array}{l}\text { EBITDA } \\
\text { margin }\end{array}$ & $\begin{array}{l}\text { Between } \\
\text { groups }\end{array}$ & .336 & 2 & .168 & 17.997 & .000 \\
\cline { 2 - 8 } & Within groups & 2.224 & 238 & .009 & & \\
\cline { 2 - 8 } & Total & 2.560 & 240 & & & \\
\hline
\end{tabular}

"Value of Fisher's statistics

Source: Authors

In order to determine which group differs from the others, the Tukey HSD post-hoc test was conducted for EBITDA margin variable (Shingala \& 
Jevtić M., et al: A New Method for Measuring Organizational Authority and...

Rajyaguru, 2015). HSD test for EBITDA margin variable is used because Leven's test of homogeneity showed equal within-group variance across the groups. For variable Business revenue/Number of Employees Tamhane test was used, because Leven's test showed that variances across the groups are different. The results are shown in the next table. In the column "arithmetic means" values with asterisks $\left({ }^{*}\right)$ indicate a statistically significant difference between the observed groups. For both dependent variables (performance indicators), groups "aligned accountability" and "higher accountability" are statistically significantly different from the group "lower accountability", while the differences between those two groups are not statistically significant.

Table 7. Tamhane and Tukey HSD post-hoc test for alignment variable

\begin{tabular}{|c|c|c|c|c|c|c|c|}
\hline \multirow{2}{*}{\multicolumn{3}{|c|}{ Dependent variables }} & \multirow{3}{*}{\begin{tabular}{r}
\multicolumn{1}{c}{$\begin{array}{c}\text { Means } \\
\text { differen } \\
\text { ce (I-J) }\end{array}$} \\
6.982
\end{tabular}} & \multirow{3}{*}{$\begin{array}{c}\text { Stand. } \\
\text { Error }\end{array}$} & \multirow{3}{*}{$\begin{array}{l}\text { Sig. } \\
.980\end{array}$} & \multicolumn{2}{|c|}{$\begin{array}{l}95 \% \text { confidence } \\
\text { interval }\end{array}$} \\
\hline & & & & & & Lower & Upper \\
\hline \multirow{6}{*}{$\begin{array}{l}\text { Business } \\
\text { revenue/Number of } \\
\text { Employees } \\
\text { (Tamhane) }\end{array}$} & \multirow{2}{*}{$\begin{array}{l}\text { Aligned } \\
\text { accounta } \\
\text { bility }\end{array}$} & $\begin{array}{l}\text { High } \\
\text { account. }\end{array}$ & & & & -41.92 & 55.88 \\
\hline & & $\begin{array}{l}\text { Low } \\
\text { account. }\end{array}$ & $77.429^{*}$ & 15.873 & .000 & 39.14 & 115.72 \\
\hline & \multirow{2}{*}{$\begin{array}{l}\text { Higher } \\
\text { account. }\end{array}$} & $\begin{array}{l}\text { Aligned } \\
\text { account. }\end{array}$ & -6.982 & 20.258 & .980 & -55.88 & 41.92 \\
\hline & & $\begin{array}{l}\text { Low } \\
\text { account. }\end{array}$ & $70.447^{\star}$ & 17.773 & .000 & 27.37 & 113.53 \\
\hline & \multirow{2}{*}{$\begin{array}{l}\text { Lower } \\
\text { account. }\end{array}$} & $\begin{array}{l}\text { Aligned } \\
\text { account. }\end{array}$ & $-77.429^{*}$ & 15.873 & .000 & -115.72 & -39.14 \\
\hline & & $\begin{array}{l}\text { High } \\
\text { account. }\end{array}$ & $-70.447^{*}$ & 17.773 & .000 & -113.53 & -27.37 \\
\hline \multirow{6}{*}{$\begin{array}{l}\text { EBITDA margin } \\
\text { (Tukey HSD) }\end{array}$} & \multirow{2}{*}{$\begin{array}{l}\text { Aligned } \\
\text { accounta } \\
\text { bility }\end{array}$} & $\begin{array}{l}\text { High } \\
\text { account. }\end{array}$ & $1.6122 \%$ & $1.4818 \%$ & .522 & $-1.8827 \%$ & $5.1071 \%$ \\
\hline & & $\begin{array}{l}\text { Low } \\
\text { account. }\end{array}$ & $8.9367 \%$ & $1.5283 \%$ & .000 & $5.3323 \%$ & $12.5411 \%$ \\
\hline & \multirow{2}{*}{$\begin{array}{l}\text { Higher } \\
\text { account. }\end{array}$} & $\begin{array}{l}\text { Aligned } \\
\text { account. }\end{array}$ & $-1.6122 \%$ & $1.4818 \%$ & .522 & $-5.1071 \%$ & $1.8827 \%$ \\
\hline & & $\begin{array}{l}\text { Low } \\
\text { account. }\end{array}$ & $7.3245 \%{ }^{*}$ & $1.6537 \%$ & .000 & $3.4242 \%$ & $11.2248 \%$ \\
\hline & \multirow{2}{*}{$\begin{array}{l}\text { Lower } \\
\text { account. }\end{array}$} & $\begin{array}{l}\text { Aligned } \\
\text { account. }\end{array}$ & $-8.9367 \%$ & $1.5283 \%$ & .000 & $-12.5411 \%$ & $-5.3323 \%$ \\
\hline & & $\begin{array}{l}\text { High } \\
\text { account. }\end{array}$ & $-7.3245 \%{ }^{*}$ & $1.6537 \%$ & .000 & $-11.2248 \%$ & $-3.4242 \%$ \\
\hline
\end{tabular}

Source: Authors

In addition to this analysis, the research examined the correlation between the Difference of Alignment and the selected performance criteria. For this purpose, a test of normality of the examined variables was firstly conducted (Todorović, 2008). 
Jevtić M., et al: A New Method for Measuring Organizational Authority and...

Table 8. Kolmogorov-Smirnov and Shapiro-Wilk test of normality

\begin{tabular}{|c|c|c|c|c|c|c|}
\hline & \multicolumn{3}{|c|}{ Kolmogorov-Smirnov ${ }^{\mathrm{a}}$} & \multicolumn{3}{|c|}{ Shapiro-Wilk } \\
\hline & Statistic & $\mathrm{df}$ & Sig. & Statistic & $\mathrm{df}$ & Sig. \\
\hline $\begin{array}{l}\text { Business Revenue/ } \\
\text { Number of Employees }\end{array}$ & 228 & 241 & .000 & .765 & 241 & .000 \\
\hline EBITDA margin & .129 & 241 & .000 & .902 & 241 & .000 \\
\hline
\end{tabular}

Source: Authors

Since the normality test signifies that the indicator values do not correspond to the normal distribution (Kolmogorov-Smirnov and Shapiro-Wilk tests have values below 0.05), Spearman's correlation coefficient was calculated.

Table 9. Spearman's test of correlation for variables Difference of Alignment and Business revenue/Number of Employees

\begin{tabular}{|c|c|c|c|c|}
\hline & & & $\begin{array}{l}\text { Difference of } \\
\text { Alignment }\end{array}$ & $\begin{array}{c}\text { Business } \\
\text { revenue/Number of } \\
\text { Employees }\end{array}$ \\
\hline \multirow[t]{6}{*}{$\begin{array}{l}\text { Spearman's } \\
\text { rho }\end{array}$} & \multirow[t]{3}{*}{$\begin{array}{l}\text { Difference of } \\
\text { Alignment }\end{array}$} & $\begin{array}{l}\text { Correlation } \\
\text { Coefficient }\end{array}$ & 1.000 & $.306^{* *}$ \\
\hline & & Sig. (2-tailed) & & .000 \\
\hline & & $\mathrm{N}$ & 241 & 241 \\
\hline & \multirow{3}{*}{$\begin{array}{l}\text { Business } \\
\text { revenue/Number } \\
\text { of Employees }\end{array}$} & $\begin{array}{l}\text { Correlation } \\
\text { Coefficient }\end{array}$ & $.306^{* *}$ & \multirow[t]{2}{*}{1.000} \\
\hline & & Sig. (2-tailed) & .000 & \\
\hline & & $\mathrm{N}$ & 241 & 241 \\
\hline
\end{tabular}

**. Correlation is significant at the 0.01 level (2-tailed).

Source: Authors

Table 10. Spearman's test of correlation for variables Difference of Alignment and EBITDA/Business revenue

\begin{tabular}{|c|c|c|c|c|}
\hline & & & $\begin{array}{c}\text { Difference of } \\
\text { Alignment }\end{array}$ & $\begin{array}{c}\text { EBITDA/Business } \\
\text { revenue }\end{array}$ \\
\hline \multirow[t]{2}{*}{$\begin{array}{l}\text { Spearman's } \\
\text { rho }\end{array}$} & $\begin{array}{l}\text { Difference of } \\
\text { Alignment }\end{array}$ & $\begin{array}{l}\text { Correlation } \\
\text { Coefficient } \\
\text { Sig. (2-tailed) } \\
\mathrm{N}\end{array}$ & $\begin{array}{r}1.000 \\
. \\
241\end{array}$ & $\begin{array}{r}.252^{* *} \\
.000 \\
241 \\
\end{array}$ \\
\hline & $\begin{array}{l}\text { EBITDA/Busin } \\
\text { ess revenue }\end{array}$ & $\begin{array}{l}\text { Correlation } \\
\text { Coefficient } \\
\text { Sig. (2-tailed) } \\
\mathrm{N}\end{array}$ & $\begin{array}{r}.252^{* *} \\
.000 \\
241\end{array}$ & $\begin{array}{r}1.000 \\
241\end{array}$ \\
\hline
\end{tabular}

${ }^{\star \star}$. Correlation is significant at the 0.01 level (2-tailed).

Source: Authors

Industrija, Vol.46, No.3, 2018

61 
Jevtić M., et al: A New Method for Measuring Organizational Authority and...

The correlation values will be interpreted according to the following levels (Cohen, 1988):
1. Low correlation
$\mathrm{r} 0=0.10-0.29$
2. Moderate correlation
$\mathrm{r} 0=0.30-0.49$
3. High correlation
$\mathrm{r} 0=0.50-1.00$

Spearman's correlation coefficients indicate moderate correlation between the variables Business Revenue/Number of Employees and Difference of Alignment $(\mathrm{r} 0=0.306, \mathrm{p}<.0005)$ and low correlation between EBITDA margin and Difference of alignment $(\mathrm{r} 0=0.252, \mathrm{p}<.0005)$.

\section{Discussion}

The new approach to measuring the alignment of organizational elements provided the results that confirm the proposed hypothesis. The analysis of the Alignment variable values and organizational performance partially confirms the hypothesis. The results showed that there is a statistically significant difference in the performance for organizations that have the value of accountability lower than the authority. Values for both performance criteria in the companies with lower accountability are worse than in the other two groups of companies.

The second variable, Difference of Alignment, shows that the alignment of authority and accountability has a positive correlation with organizational effects. Correlation is slightly higher for variable Business revenue/Number of Employees in relation to the EBITDA margin variable. Based on the correlation results, calculated determination coefficient is $r^{2}=0.094$, and $r^{2}=$ 0.063 , which means that $9.4 \%$ of the Business revenue variable per number of employees and $6.3 \%$ of the EBITDA margin variability can be explained by the alignment of authority and accountability.

The obtained results are in accordance with the previous research that examined the case of lower managerial accountability (Merchant \& Van der Stede, 2007). As other research from this field, the provided results have certain shortcomings that should be highlighted to derive proper conclusions. Firstly, this paper develops a new way of measuring authority and accountability, and thus a new way of measuring their alignment. In order to determine validity and usefulness of the suggested model it is necessary to conduct additional research. Secondly, although measuring authority and accountability is quantified, this approach has a certain level of subjectivity (Meier \& O'Toole Jr, 2013). For the purpose of this research a 7-level Likerttype scale was developed with descriptions for assigning the values for the span of authority and span of accountability, but there is a certain degree of 
Jevtić M., et al: A New Method for Measuring Organizational Authority and...

subjectivity in assessing the value of the elements on the scale (Jevtic et al., 2018).

On the other hand, the results did not imply that higher managerial accountability leads to the higher organizational effects observed in this research. The reason for this may lay in the selection of the performance criteria. Namely, the selected indicators are indicators of system performance and show how well the existing resources are used. It would be interesting to examine whether there is a difference between organizations that have higher levels of accountability than the authority by using other performance indicators. It is possible that the selection of other performance criteria (i.e. revenue from new products, number of innovations, etc.) could indicate the difference between the companies with higher accountability and the rest of the sample. It should be examined whether innovation indicators would indicate better results when accountability is higher than the authority.

\section{Conclusion}

This paper examines the impact of application of controllability principle and suggests a different way of measuring authority and accountability in organizations. Quantification of authority and accountability variables enables comparison of these elements by different logic operations (higher, lower, equal). By defining another approach to measuring authority and accountability the research tried to increase the level of objectivity by quantifying their values. Although there is a high interest for the application of controllability principle, there are few empirical studies that have quantified approach for measuring alignment. Most studies did not get any further than the descriptive analysis, that is, they mainly investigated the consequences of disregarding this principle.

This research opens many questions related to measuring the influence of controllability principle application at the lower hierarchy level. For that purpose, it is necessary to adjust the measurement model for the lower positions and compare it with the results related to the organizational parts, teams and projects. Future research should choose alternative measures of managerial performance that comprise activity differences for different managerial positions. To confirm the proposed methodology, the model should be tested in different economies and another set of companies. If those researches show the positive influence of alignment of authority and accountability on different performance indicators, there could be derived a general conclusion applicable for all organizations and organizational levels.

Regardless of the limitation of this research, the suggested model contributes to managerial theory and practice. The proposed way of measuring authority 
Jevtić M., et al: A New Method for Measuring Organizational Authority and...

and accountability and quantified values enable easier understanding of controllability principle application and alignment of organizational elements. The results of this research should highlight the importance of organizational elements alignment to those managers who deal with organizational design and enable them to eliminate dysfunctional solutions. The proposed model also indicates possible levers of change that should be in managerial focus.

The important practical implications stem from the insight into the results achieved by organizations in which accountability is lower than the authority. On the other hand, the results also show the practical reasons for increasing the accountability of managerial positions beyond the zone of their influence. Such a violation of the controllability principle does not lead to a decrease in performance and can lead managers to innovative thinking and activity. Increasing managers' accountability for outcomes beyond their direct impact can have a positive effect on the improvement of existing products and processes.

\section{References}

Aghion, P., \& Tirole, J. (1997). Formal and Real Authority in Organizations. Journal of Political Economy, 105(1), 1-29. doi:10.1086/262063

Antle, R., \& Demski, J.S. (1988). The controllability principle in responsibility accounting. Accounting Review, 700-718.

Arya, A., Glover, J., \& Radhakrishnan, S. (2007). The Controllability Principle in Responsibility Accounting: Another Look. In R. Antle, F. Gjesdal, \& P.J. Liang (Eds.), Essays in Accounting Theory in Honour of Joel S. Demski. (pp. 183-198). New York, NY: Springer Nature. doi:10.1007/978-0-387-30399-4_9

Bedford, D.S., Malmi, T., \& Sandelin, M. (2016). Management control effectiveness and strategy: An empirical analysis of packages and systems. Accounting, Organizations and Society, 51, 12-28. doi:10.1016/j.aos.2016.04.002

Bouwens, J., \& Van Lent, L. (2007). Assessing the Performance of Business Unit Managers. Journal of Accounting Research, 45(4), 667-697. doi:10.1111/j.1475679x.2007.00251.x

Burkert, M., Fischer, F.M., \& Schäffer, U. (2011). Application of the controllability principle and managerial performance: The role of role perceptions. Management Accounting Research, 22(3), 143-159. doi:10.1016/j.mar.2011.03.002

Cohen, J. (1988). Statistical Power Analysis for the Behavioral Sciences, 2nd ed.. Hidllsdale, New Jersey: Erlbaum.

Daft, R.L., Jonathan, M., \& Willmott, H. (2010). Organization theory and design. Cengage learning EMEA.

Fischer, F.M. (2010). The Application of the Controllability Principle and Managers' Responses: A role theory perspective. Springer Science and Business Media.

Frow, N., Marginson, D., \& Ogden, S. (2005). Encouraging strategic behaviour while maintaining management control: Multi-functional project teams, budgets, and the negotiation of shared accountabilities in contemporary 
Jevtić M., et al: A New Method for Measuring Organizational Authority and...

enterprises. Management Accounting Research, 16(3), 269-292. doi:10.1016/j.mar.2005.06.004

Giraud, F., Langevin, P., \& Mendoza, C. (2008). Justice as a rationale for the controllability principle: A study of managers' opinions. Management Accounting Research, 19(1), 32-44. doi:10.1016/j.mar.2007.09.002

Goold, M. (1993). Strategic control: Establishing milestones for long-term performance. Addison-Wesley.

Jevtić, M. (2013). Pristup projektovanju organizacije zasnovan na merenju usklađenosti elemenata organizacije. Fakultet organizacionih nauka.

Jevtić, M., Jovanović, M., \& Krivokapić, J. (2018). A New Approach to Measuring the Correlation of Organizational Alignment and Performance. Management: Journal of Sustainable Business and Management Solutions in Emerging Economies, 23(1), 41. doi:10.7595/management.fon.2017.0029

Kaplan, S.N., \& Ruback, R.S. (1995). The Valuation of Cash Flow Forecasts: An Empirical Analysis. The Journal of Finance, 50(4), 1059-1093. doi:10.1111/j.1540-6261.1995.tb04050.x

Khandwalla, P.N. (1973). Viable and Effective Organizational Designs of Firms. Academy of Management Journal, 16(3), 481-495. doi:10.2307/255008

Lunenburg, F.C. (2012). Organizational structure: Mintzberg's framework. International journal of scholarly, academic, intellectual diversity, 14(1); 1-8.

Meier, K.J., \& Bohte, J. (2000). Ode to Luther Gulick: Span of control and organizational performance. Administration and Society, 32(2), 115-137. doi:10.1177/00953990022019371

Meier, K.J., \& O'Toole, L.J. (2013). Subjective Organizational Performance and Measurement Error: Common Source Bias and Spurious Relationships. Journal of Public Administration Research and Theory, 23(2), 429-456. doi:10.1093/jopart/mus057

Merchant, K.A. (1989). Rewarding results: Motivating profit center managers. Harvard Business School Press.

Merchant, K.A., \& Otley, D.T. (2006). A Review of the Literature on Control and Accountability. In Handbooks of management accounting research. (pp. 785802). 2 (pp. 785-802). doi:10.1016/s1751-3243(06)02013-x

Merchant, K.A., \& Van der Stede, W.A. (2007). Management control systems: Performance measurement, evaluation and incentives. Pearson Education.

Mintzberg, H. (1979). The structuring of organisations: A synthesis of the research. New Jersey.

Mintzberg, H. (1989). The Structuring of Organizations. In D. Asch \& C. Bowman (Eds.), Readings in Strategic Management. (pp. 322-352). London: Springer Nature. doi:10.1007/978-1-349-20317-8_23

Montana, P.J., \& Charnov, B.H. (2000). Management, Barron's educational series. New York.

Ocansey, E.O., \& Enahoro, J.A. (2012). Determinant controllability of responsibility accounting in profit planning. Canadian social science, 8(6), 91.

Otley, D. (2016). The contingency theory of management accounting and control: 1980-2014. Management Accounting Research, 31, 45-62. doi:10.1016/j.mar.2016.02.001

Pallant, J. (2011). SPSS priručnik za preživljavanje: Postupni vodič kroz analizu podataka pomoću SPSS-a. Beograd: Mikro knjiga. 4th Edition; Trans. 
Jevtić M., et al: A New Method for Measuring Organizational Authority and...

Perrow, C. (1986). Economic theories of organization. Theory and Society, 15(1-2), 11-45. doi:10.1007/bf00156926

Shingala, M.C., \& Rajyaguru, A. (2015). Comparison of post hoc tests for unequal variance. International Journal of New Technologies in Science and Engineering, 2(5); 22-33.

Simons, R. (1994). Levers of control: How managers use innovative control systems to drive strategic renewal. Harvard Business Press.

Simons, R. (2005). Levers of organization design: How managers use accountability systems for greater performance and commitment. Harvard Business Press.

Simons, R. (2010). Accountability and Control as Catalysts for Strategic Exploration and Exploitation: Field Study Results. SSRN Electronic Journal, doi:10.2139/ssrn.1534745

Simons, R. (2013). The Entrepreneurial Gap: How Managers Adjust Span of Accountability and Span of Control to Implement Business Strategy. SSRN Electronic Journal, doi:10.2139/ssrn.2280355

Stevens, S.S. (1946). On the Theory of Scales of Measurement. Science, 103(2684), 677-680. doi:10.1126/science.103.2684.677

Todorović, D. (2008). Metodologija psiholoških istraživanja. Beograd: Društvo psihologa Srbije.

Zhang, Y., Zhou, J., \& Zhou, N. (2007). Audit committee quality, auditor independence, and internal control weaknesses. Journal of Accounting and Public Policy, 26(3), 300-327. doi:10.1016/j.jaccpubpol.2007.03.001 
Jevtić M., et al: A New Method for Measuring Organizational Authority and...

Appendix 1. Scales from the questionnaire used for the research

In the research, the authors developed a 7-level Likert-type scale for determination of the span of control and span of accountability. In order to determine the level of spans, the respondents had the descriptions for each grade from the scale. The scales are shown in Table 11 and Table 12.

Table 11. Scale for measuring span of authority

\begin{tabular}{c|l}
\hline Value & \multicolumn{1}{|c}{ Description of influence and authorities of a position } \\
\hline II & $\begin{array}{l}\text { Basic responsibilities are related to the routine activities that are } \\
\text { performed in structured situations (environment). Side assistance is } \\
\text { expected for solving unpredicted problems. Work under strict } \\
\text { supervision. Interaction within the organization unit. No initiative is } \\
\text { expected. There is no use of the valuable resources. }\end{array}$ \\
\hline $\begin{array}{l}\text { Basic responsibilities are related to the various activities that are } \\
\text { performed in different, but structured situations (environment). Work } \\
\text { under routine supervision. Minor discretion is used for solving } \\
\text { problems or questions. Work without frequent reliance on others. } \\
\text { Interaction within the whole organization. There are certain contacts } \\
\text { with users or suppliers. There is a certain impact within their domain. }\end{array}$ \\
$\begin{array}{l}\text { Basic responsibilities are related to the wider span of activities, } \\
\text { sometimes complex and non-routine, in diversified environment. } \\
\text { Work under general supervision. There is discretion in identifying } \\
\text { and solving complex problems and tasks. Specific instructions are } \\
\text { given. Work improvement is checked according to the given phases. } \\
\text { Interaction and influence within team members (production/project). } \\
\text { Contacts with users or suppliers are frequent. } \\
\text { Non-core business: internal services. There is no critical influence on } \\
\text { achieving the organizational goals. There is a certain control, the } \\
\text { manager is responsible for making your own schedule and the } \\
\text { others. There is a certain influence on non-core activities. Core } \\
\text { business: Works with suppliers and customers. Negligible influence } \\
\text { on core activities. }\end{array}$ \\
\hline
\end{tabular}


Jevtić M., et al: A New Method for Measuring Organizational Authority and...

\begin{tabular}{|c|c|}
\hline Value & Description of influence and authorities of a position \\
\hline & $\begin{array}{l}\text { Basic responsibilities are related to a wider range of technical or } \\
\text { professional activities, in different contexts. Work under general } \\
\text { supervision. Significant responsibilities and autonomy. Manager } \\
\text { independently plans fulfilment of the required activities and goals. } \\
\text { Manager affects the work of the team and colleagues' specialists } \\
\text { internally. He is responsible for the users and suppliers at the work } \\
\text { order level. There is a certain responsibility for the work of others } \\
\text { and the allocation of resources. Manager participates in external } \\
\text { activities in accordance with his specialization. Decisions affect the } \\
\text { success of the project and the team. } \\
\text { Non-core business: Manager has a certain impact on achieving the } \\
\text { goals of the organization through the internal services provision. } \\
\text { There is a greater influence on non-core activities. Core business: } \\
\text { Manager is responsible for users of users and suppliers at the work } \\
\text { order level. There is a certain influence on core activities. }\end{array}$ \\
\hline & $\begin{array}{l}\text { Challenging scope and variety of complex technical or professional } \\
\text { activities. Work requires the application of fundamental principles in } \\
\text { unpredictable circumstances. There is an understanding of the } \\
\text { relationship between specialization and broader organizational/ } \\
\text { consumer demands. There is full responsibility for technical work or } \\
\text { responsibilities for the project/organizational unit. Tasks are set in } \\
\text { the form of goals. Manager independently sets the goals of a team } \\
\text { and delegates tasks. Work is often self-initiated. Work affects the } \\
\text { organization, customers, suppliers, and industry specialists. There is } \\
\text { significant responsibility for the work of others and the allocation of } \\
\text { resources. Decisions affect the success of the assigned projects, i.e. } \\
\text { results, deadlines and budget. Manager develops business } \\
\text { relationships with clients. Core business: Great impact on goal } \\
\text { achievement in the core business. }\end{array}$ \\
\hline & $\begin{array}{l}\text { Highly complex activities that include technical, financial and quality } \\
\text { aspects. The work consists of the creative application of a wide } \\
\text { range of technical and/or management principles. Manager sets the } \\
\text { goals of the organization and delegates tasks. He is responsible for } \\
\text { his activities and decisions, as well as for the activities and decisions } \\
\text { of his subordinates. Manager affects a significant part of the } \\
\text { organization, customers, suppliers, and industry. His decisions affect } \\
\text { the work of employees in the organization, level of goals } \\
\text { achievement and financial effects. Manager develops relationships } \\
\text { with customers, suppliers and leaders in the industry. Highly } \\
\text { sophisticated and strategic work. He initiates and manages technical } \\
\text { and business changes. Core business: High impact on defining and } \\
\text { achieving the goals of the organization. }\end{array}$ \\
\hline
\end{tabular}


Jevtić M., et al: A New Method for Measuring Organizational Authority and...

\begin{tabular}{l|l}
\hline Value & \multicolumn{3}{|c}{ Description of influence and authorities of a position } \\
\hline \multirow{1}{*}{} & $\begin{array}{l}\text { Basic responsibilities are related to the formulation and } \\
\text { implementation of the strategy. Manager applies the highest level of } \\
\text { management and leadership skills. He has a deep understanding of } \\
\text { the information systems industry and the development of new } \\
\text { technologies and their impact in the broader business environment. } \\
\text { Manager has authority over all aspects of significant work areas, } \\
\text { including the definition and implementation of the organization's } \\
\text { policy. He has the responsibility for all decisions and activities - his } \\
\text { own and of all subordinates. Managerial decisions are critical to the } \\
\text { organization's success. He improves the use of the information } \\
\text { systems within and outside the organization, and develops long-term } \\
\text { strategic relationships with customers and industry leaders. }\end{array}$ \\
\hline
\end{tabular}

Table 12. Scale for measuring span of accountability

\begin{tabular}{|c|c|}
\hline Value & Description of accountability of a position \\
\hline & $\begin{array}{l}\text { The basic responsibilities of the law, the collective agreement, the } \\
\text { employment contract, etc. are not respected. }\end{array}$ \\
\hline & $\begin{array}{l}\text { The accountability defined by law, general and specific collective } \\
\text { agreement, the employment contract etc. }\end{array}$ \\
\hline & $\begin{array}{l}\text { The accountability for applying the procedures, instructions, and } \\
\text { standards without too much creativity and autonomy for achieving } \\
\text { the organizational effects. }\end{array}$ \\
\hline & $\begin{array}{l}\text { The accountability for achieving goals in the support processes, } \\
\text { budget performance, with a greater possibility for choosing how the } \\
\text { organizational effects will be achieved. }\end{array}$ \\
\hline & $\begin{array}{l}\text { The accountability for achieving goals in basic processes, and } \\
\text { organizational effects related to the inputs, cost price, etc. }\end{array}$ \\
\hline & $\begin{array}{l}\text { The accountability for achieving organizational goals, and } \\
\text { organizational effects related to financial indicators, achieved } \\
\text { income, revenue, etc. }\end{array}$ \\
\hline & $\begin{array}{l}\text { The accountability for strategic organizational effects, ROI, market } \\
\text { share, value of shares, etc. }\end{array}$ \\
\hline
\end{tabular}

